\title{
PENGARUH UMUR LEPAS SAPIH DAN UMUR INDUK TERHADAP PRODUKSI SUSU SAPI PERAH PERANAKAN FRIESIAN HOLSTEIN (PFH)
}

\author{
Enike Dwi Kusumawati' ${ }^{1}$, Syam Rahadi ${ }^{2}$, Juventus Peso ${ }^{1}$, Aju Tjatur Nugroho \\ Krisnaningsih ${ }^{1}$ \\ ${ }^{1}$ Fakultas Peternakan Universitas Kanjuruhan Malang \\ ${ }^{2}$ Fakultas Peternakan Universitas Halu Oleo Kendari \\ e-mail: enike@unikama.ac.id
}

\begin{abstract}
ABSTRAK
Penelitian ini dilaksanakan di Pujon Kabupaten Malang. Tujuan penelitian ini adalah untuk mengetahui pengaruh umur lepas sapih dan umur induk terhadap produksi susu sapi perah PFH. Materi yang digunakan dalam penelitian ini adalah 27 ekor induk sapi perah PFH dengan kelompok umur 3-4 tahun, 5-6 tahun dan 7-8 tahun sebanyak 9 ekor dari berbagai kelompok umur. Metode yang dipakai adalah studi kasus dengan teknik pengambilan data secara observasi dan wawancara dengan pemilik. Data yang diamati dalam penelitian ini adalah jumlah produksi susu dalam waktu 30 hari, umur induk dan umur pedet saat penyapihan. Analisis data menggunakan Rancangan Acak Kelompok (RAK) Faktorial. Hasil penelitian menunjukkan bahwa umur induk 5-6 tahun menghasilkan produksi susu yang terbaik sebesar 12,72 $\pm 0,77$ liter, kemudian dari kelompok umur 7-8 tahun sebesar 11,31 $\pm 1,75$ liter dan yang terakhir umur 3-4 tahun memberikan produksi susu yang terendah sebesar $10,94 \pm 0,41$ liter. Rata-rata produksi susu umur lepas sapih 1 bulan sebesar 13,00 $\pm 0,38$ liter. Rata-rata produksi susu umur lepas sapih 2 bulan sebesar 11,77 $\pm 0,72$ liter. Rata-rata produksi susu umur lepas sapih 3 bulan sebesar 10,96 $\pm 0,50$ liter. Dari hasil penelitian dapat disimpulkan bahwa terdapat pengaruh umur induk terhadap produksi susu sapi perah $\mathrm{PFH}$, umur induk 5-6 tahun memberikan produksi tertinggi yaitu 12,72 $\pm 0,77$ liter. Umur lepas sapih tidak memberikan pengaruh terhadap produksi susu sapi perah PFH kemudian tidak terdapat interaksi antara umur induk dan umur lepas sapih terhadap produksi susu.
\end{abstract}

Kata Kunci: produksi susu, peternak, sapi prah

\begin{abstract}
The aim of the study was to know the influence of weaning and dairy cows age toward Filial Friesian Holstein (PFH) production milk. The research was conducted in village area district Pujon Malang. Based on the descriptive surve method of collecting primary data and other supporting data. Primary data obtained from observation by interviewing farmers in the village dairy cows Pujon Malang District. Other data obtained from breeders group data, literature, internet and analyzed qualitatively. The results showed that weaning age didn't significant affected on the production milk but dairy cows age significant affected on the production milk, then interaction between weaning and dairy cows age didn't significant toward PFH production milk.
\end{abstract}

Keywords: dairy cows, farmers, production milk, 


\section{PENDAHULUAN}

Produktivitas seekor ternak ditentukan oleh faktor genetik, lingkungan serta interaksi faktor genetik dan faktor lingkungan, seperti manajemen, pakan dan musim. Peningkatan produktivitas ternak sapi perah dapat dilakukan melalui perbaikan mutu genetik dan lingkungan. Manajemen pemeliharaan merupakan salah satu faktor lingkungan yang dapat mempengaruhi produktivitas ternak sapi perah seperti umur lepas sapih pedet dan umur induk terhadap produksi susu induk (Riski et al., 2016).

Produksi susu yang optimal pada setiap laktasi berkaitan dengan usaha peternak dalam melakukan manajemen pemeliharaan, antara lain menentukan umur lepas sapih pedet dari induknya. Produksi susu sapi perah per laktasi akan meningkat terus sampai dengan laktasi yang keempat atau pada umur enam sampai tujuh tahun dan mengalami penurunan produksi susu pada umur delapan tahun (Hafez and Hafez, 2008).

Manajemen pemeliharaan pedet yang optimal sejak lahir sangat diperlukan untuk memperoleh sapi yang mempunyai produksi dan produktivitas yang tinggi yang siap menggantikan sapi yang sudah tidak berproduksi lagi, baik sebagai induk maupun pemacek. Target pemeliharaan pedet periode prasapih adalah mencapai bobot badan $65 \mathrm{~kg}$ pada saat umur 8 minggu atau umur sapih.

Penyapihan bertujuan untuk menghemat biaya pembesaran pedet dan meningkatkan volume susu yang dapat dijual. Penyapihan dini memberikan keuntungan yaitu mengurangi biaya pakan, mengurangi biaya tenaga kerja, dan mengurangi timbulnya gangguan pencernaan dan scours. Pemberian susu dalam bentuk pelet memudahkan peternak dalam penyapihan dini yaitu pada saat umur 2-3 minggu.

Pada waktu pedet mencapai umur 3,5 bulan, tak diberikan air susu lagi, sebab pada saat itu pedet sudah memperoleh makanan penguat dan hijauan seperti pada sapi dewasa, hanya volumenya berbeda (Riski et al., 2016). Berdasarkan uraian diatas maka diperlukan penelitian tentang pengaruh umur induk dan umur lepas sapih terhadap produksi susu sapi perah PFH

\section{.MATERI DAN METODE}

\section{Lokasi dan Waktu Penelitian}

Penelitian dilaksanakan di Kec. Pujon Kabupaten Malang.

\section{Materi Penelitian}

Materi yang digunakan dalam penelitian ini adalah 27 ekor induk sapi perah PFH dan data yang diambil adalah data sekunder dari produksi susu selama 30 hari, umur induk dan umur pedet saat penyapihan.

\section{Metode Penelitian}

Data yang diamati dalam penelitian ini adalah jumlah produksi susu dalam waktu 30 hari, umur induk dan umur pedet saat penyapihan (Tabel 1.).

Tabel 1. Jumlah kelompok umur induk dan umur lepas sapih

\begin{tabular}{cccc}
\hline \multirow{2}{*}{ Perlakuan } & \multicolumn{3}{c}{ Kelompok Umur Induk } \\
\cline { 2 - 4 } & $3-4$ thn & $5-6$ thn & $7-8$ thn \\
\hline Umur Lepas Sapih (1 bulan) & 3 ekor & 3 ekor & 3 ekor \\
Umur Lepas Sapih (2 bulan) & 3 ekor & 3 ekor & 3 ekor \\
Umur Lepas Sapih (3 bulan) & 3 ekor & 3 ekor & 3 ekor \\
\hline
\end{tabular}

Metode penelitian adalah studi kasus, dengan pengelompokan umur induk sapi perah $\mathrm{PFH}$ menjadi tiga bagian yaitu umur 3-4 tahun, 5-6 tahun dan 7-8 tahun masing-masing 9 ekor. Umur lepas sapih dibagi menjadi tiga kelompok yaitu umur lepas sapih 1 bulan, umur lepas sapih 2 bulan dan umur lepas sapih 3 bulan. Jumlah 
masing-masing dalam pengelompokan umur lepas sapih sebanyak 9 ekor dengan perincian umur 3-4 tahun 3 ekor, umur 5-6 tahun 3 ekor dan umur 7-8 tahun 3 ekor.

\section{Analisis data}

Data hasil penelitian dianalisis menggunakan Rancangan Acak Kelompok (RAK) Faktorial. Faktor pertama adalah umur lepas sapih dan faktor kedua adalah umur induk.

\section{HASIL DAN PEMBAHASAN}

\section{Keadaan Umum Lokasi Penelitian}

Kecamatan Pujon mempunyai wilayah yang cukup luas terdiri dari 10 desa yang terletak di wilayah selatan. Kecamatan Pujon beriklim tropis karena pengaruh musim angin barat dan angin musim timur, maka di daerah ini terjadi dua pergantian musim kemarau dan musim penghujan, temperatur berkisar antara $20-29^{\circ} \mathrm{C}$. Daerah ini sebagian besar sifat tanah kurang subur karena berbahan batuan, kapur dan napal. Sehingga keberadaan mata air dan sungai kurang namun itu bukan kendala bagi masyarakat untuk mengembangkan agrobisnis peternakan.

Pujon adalah sebuah kecamatan di Kabupaten Malang, Provinsi Jawa Timur, Indonesia. Kecamatan Pujon ini terdapat Koperasi Susu Sapi yang mengolah susu sapai dari seluruh desa yang ada di Kecamatan Pujon yang bernama Koperasi SAE Pujon. Selama ini Pujon terkenal dengan hasil susu sapinya. Selain penghasil Susu sapi segar, Pujon juga dikenal dengan penghasil sayuran seperti kol, wortel, tomat dan sawi. Pada musim kemarau suhu di Pujon bisa mencapai $8^{\circ} \mathrm{C}$ di malam hari dan $18^{\circ} \mathrm{C}$ di siang hari. Secara administratif wilayah Kecamatan Pujon terdiri atas 10 desa dengan jumlah penduduk 65.268 jiwa dengan komposisi sebagian besar angkatan kerjanya $92,76 \%$ berkecimpung pada sektor petanian dan peternakan (BPS, 20017).

\section{Gambaran Umum Responden}

Pekerjaan utama peternak adalah petani, tingkat pendidikan formal responden rata-rata SD dan tidak berpendidikan khusus peternakan. Para peternak mendapatkan pendidikan dan informasi peternakan melalui: pendidikan informal berupa kursus dan pelatihan dari dinas peternakan dan KUD, musyawarah kelompok tani ternak, dari saudara bahkan hanya informasi turun temurun dari orang tua.

Pemanfaatan lahan oleh peternak antara lain untuk kandang sapi laktasi dan bunting, kandang dara, kandang pedet, gudang pakan dan kebun rumput. Sering kali karena keterbatasan pemilikan lahan yang sempit maka beberapa kelompok peternak memanfaatkan lahan secara bersama- sama.

Umumnya ternak dikandangkan sepanjang hari karena sempitnya lahan. Frekuensi pemberian pakan umumnya dua kali yaitu pagi dan sore dalam sehari dalam bentuk hijauan dan konsentrat, pemberian pakan lebih didasarkan pada kondisi aktivitas sapi yaitu, sapi laktasi atau bunting dan berdasarkan jumlah produksi susunya. Pemberian pakan menurut umur dan berat badan sangat jarang dijumpai.

Pemberian pakan hijauan dan konsentrat proporsinya dipengaruhi oleh ketersedian hijauan yang melimpah dimusim penghujan, sedangkan dimusim kemarau ditambahkan jerami limbah pertanian. Secara klimatologis Pujon kurang sesuai untuk budidaya sapi perah namun atas dikembangkannya sapi perah PFH yang teradaptasi dan karena kegigihan peternak dan kondisi yang kompak antara KUD dan pemerintah lambat laun sapi perah di Malang mampu menghasilkan produksi optimal dengan rata-rata 10,2 liter/ekor per hari.

Usaha peternakan pakan atau ransum merupakan faktor yang penting. Pada daerah tropis musim kawin lebih dipengaruhi oleh faktor pakan daripada panjangnya siang hari. Tanpa pakan yang baik dan jumlah yang memadai, maka meskipun bibit ternak unggul akan kurang memperlihatkan keunggulannya jika pakan yang diberikan sangat terbatas. Sapi 
diberikan pakan daun-daunan sebagai pakan dasar dan pakan tambahan (konsentrat). Pakan tambahan dapat disusun dari bungkil kalapa, bungkil kedelai, dedak, tepung ikan ditambah mineral dan vitamin. Pakan dasar umumnya adalah rumput kayangan, daun lamtoro, gamal, daun nangka, dan sebagainya. Pemberian hijauan diberikan mencapai $3 \%$ berat badan (dasar bahan kering) atau $10-15 \%$ berat badan (dasar bahan segar) (Amin, 2014; Sutiyono et al., 2017; Kurniadi et al., 2009; Sari et al., 2017).

Peternak di Pujon memberikan pakan kepada induk sapi berupa pakan dasar yang terdiri dari kalindra, rumput gajah, lamtoro, turi dan rumput kayangan sedangkan pakan tambahan diberikan untuk mempengaruhi pertambahan bobot badan dan produksi susu. Pakan hijauan diberikan dua kali sehari dengan jumlah yang tidak terbatas sedangkan pakan konsentrat diberikan dua kali sehari dengan jumlah 3-4 kg.

Pada pengembangan ternak dikenal dua cara perkawinan yaitu perkawinan secara alami dan inseminasi buatan (IB). Peternak sapi perah PFH di Pujon menggunakan perkawinan secara IB disebabkan oleh beberapa alasan, peternak tidak perlu memiliki pejantan dalam jumlah banyak. sehingga dapat menghemat biaya dan mengurangi resiko akibat serangan pejantan. Pejantan yang dipakai dalam program IB telah diseleksi secara teliti dari hasil perkawinan betina-betina dengan pejantan unggul. Penularan penyakit dapat dicegah melalui IB karena pejantan yang dimanfaatkan sehat dan bebas dari penyakit menular.

Menurut Pineda (2003) ternak-ternak betina menjadi estrus pada waktu yang teratur, namun berbeda dari spesies satu ke spesies lainnya. Interval waktu tersebut, mulai dari permulaan periode estrus yang pertama sampai ke periode estrus yang berikutnya, disebut siklus estrus. Estrus merupakan fase dalam siklus estrus yang ditandai oleh sikap penerimaan hewan betina terhadap hewan jantan untuk aktivitas reproduksi. Pencirian estrus, disebutkan oleh Hafez and Hafez (2008) melalui pengeluaran lendir jernih dan encer selama birahi yang membentuk pola kristalisasi seperti pakis dan setelah ovulasi serta fase estrus akhir, lendir itu menjadi massa putih kental yang mengandung banyak elemen sel bertanduk. Besar kemungkinannya faktor curah hujan dan pertumbuhan tanaman pakan ternak dapat berpengaruh terhadap estrus dan kesuburan hewan.

Menurut Hafez and Hafez (2008), estrus akan terulang kembali kurang lebih pada 21 hari berikutnya, bila terjadi kegagalan perkawinan yang ditandai ternak tidak menjadi bunting. Siklus ini dikontrol secara langsung oleh hormon dari ovari dan secara tidak langsung oleh hormon dari Adenohipofisis dari kelenjar pituitary (Pineda, 2003).

Sapi yang birahi (fase estrus) ditandai dengan adanya kemerahan, bengkak dan alat kelamin luar yang hangat, adanya lendir yang kental dan bersih yang menggantung keluar dari alat kelamin dan diikuti dengan tingkah laku homoseksual, suara bengah-bengah pada ternak tersebut. Jika dipalpasi perektal maka uterus terasa kontraksi, tegang, mengeras dengan permukaan tidak rata, cervik relaksasi dan pada ovarium terdapat folikel de graaf yang membesar dan sudah matang. Secara normal ovulasi pada sapi terjadi saat mendekati akhir estrus sekitar 12-18 jam setelah terjadinya estrus sehingga pada saat inilah waktu yang tepat untuk mengawinkan sapi (Hafez and Hafez, 2008). Keberhasilan IB juga tergantung dari Petugas Inseminator yang terampil dalam melakukan perkawinan, pengetahuan peternak tentang estrus, kondisi ternak induk.

\section{Produksi Susu}

Produksi susu merupakan sifat kuantitatif yang mempunyai nilai ekonomis tinggi. Produksi susu rata-rata sapi PFH di Indonesia 10 liter per ekor per hari atau kurang lebih $3.050 \mathrm{~kg} /$ laktasi dengan bobot anak sapi Friesian Holstein (FH) yang baru 
dilahirkan mencapai $43 \mathrm{~kg}$. Hasil penelitian tentang pengaruh umur lepas sapih dan umur induk sapi PFH di Pujon terhadap produksi Susu dapat di lihat di Tabel 2.

Tabel 2. Rata-Rata Produksi susu pada berbagai Umur Lepas Sapih dan Umur Induk Sapi Perah PFH

\begin{tabular}{|c|c|c|c|c|c|}
\hline \multirow{2}{*}{$\begin{array}{l}\text { Umur } \\
\text { sapih }\end{array}$} & \multirow{2}{*}{ Umur induk } & \multicolumn{3}{|c|}{ Bulan laktasi } & \multirow{2}{*}{ Rata-rata } \\
\hline & & 1 & 2 & 3 & \\
\hline \multirow{3}{*}{1 bulan } & 3-4 Tahun & 11,00 & 12,78 & 10,78 & $11,52 \pm 1,10$ \\
\hline & 5-6 Tahun & 13,28 & 13,6 & 13,22 & $13,37 \pm 0,20$ \\
\hline & 7-8 Tahun & 12,63 & 13,35 & 9,00 & $11,66 \pm 2,33$ \\
\hline \multirow{3}{*}{2 bulan } & 3-4 Tahun & 11,17 & 15,55 & 10,88 & $12,53 \pm 2,62$ \\
\hline & 5-6 Tahun & 13,17 & 13,05 & 12,88 & $13,03 \pm 0,15$ \\
\hline & 7-8 Tahun & 10,05 & 13,05 & 9,00 & $10,70 \pm 2,10$ \\
\hline \multirow{3}{*}{3 bulan } & 3-4 Tahun & 11,25 & 10,17 & 9,85 & $10,42 \pm 0,73$ \\
\hline & 5-6 Tahun & 12,19 & 12,53 & 10,94 & $11,89 \pm 0,84$ \\
\hline & 7-8 Tahun & 11,27 & 11,53 & 9,85 & $10,88 \pm 0,90$ \\
\hline
\end{tabular}

Hasil analisa statistik menunjukkan bahwa tidak ada pengaruh $(\mathrm{P}>0,05)$ umur lepas sapih terhadap produksi susu, kemudian terdapat perbedaan yang nyata $(\mathrm{P}<0,05)$ umur induk terhadap produksi susu dan tidak terdapat interaksi umur sapih dan umur induk terhadap produksi susu. Berdasarkan hasil analisa statistik, umur lepas sapih tidak memberikan pengaruh terhadap produksi susu, secara numerik produksi susu yang terbaik sebesar 13 liter/ekor per hari pada umur lepas sapih 1 bulan. Hal ini disebabkan karena pedet sudah tidak menyusu pada induk sehingga produksi susu induk lebih banyak. Kemudian rataan produksi susu sapi PFH mengalami penurunan pada umur lepas sapih 2 dan 3 bulan sebesar 11,77 dan 10,96 liter/ekor per hari, seperti tertera di Tabel 3. Hal ini disebabkan karena periode menyusu pada induk lebih lama sehingga produksi air susu yang dihasilkan lebih sedikit.
Tabel 3. Rata- Rata Produksi Susu PFH di Pujon Pada Umur Lepas Sapih yang Berbeda

\begin{tabular}{lccc}
\hline \multirow{2}{*}{ Keterangan } & \multicolumn{3}{c}{ Umur lepas sapih (bulan) } \\
\cline { 2 - 4 } & 1 bulan & 2 bulan & 3 bulan \\
\hline Produksi & 13,00 & 11,77 & 10,96 \\
susu (liter) & $\pm 0,38$ & $\pm 0,72$ & $\pm 0,50$
\end{tabular}

Hasil analisa statistik menunjukkan tidak terdapat interaksi antara umur induk dan umur lepas sapih terhadap produksi Secara numerik umur lepas sapih dan umur induk yang paling baik dalam memproduksi susu masing-masing adalah umur 1 bulan dan 5-6 tahun. Umur induk memberikan pengaruh yang nyata terhadap produksi susu, dapat dilihat pada Tabel 4 dan Gambar 1.

Tabel 4. Rata-rata produksi susu pada berbagai kelompok umur induk

\begin{tabular}{cc}
\hline Umur Induk & Rataan \\
\hline P1 (umur 3-4 tahun) & $10,94 \pm 0,41^{\mathrm{a}}$ \\
P3 (umur 7-8 tahun) & $11,31 \pm 1,75^{\mathrm{b}}$ \\
P2 (umur 5-6 tahun) & $12,72 \pm 0,77^{\mathrm{c}}$ \\
\hline
\end{tabular}

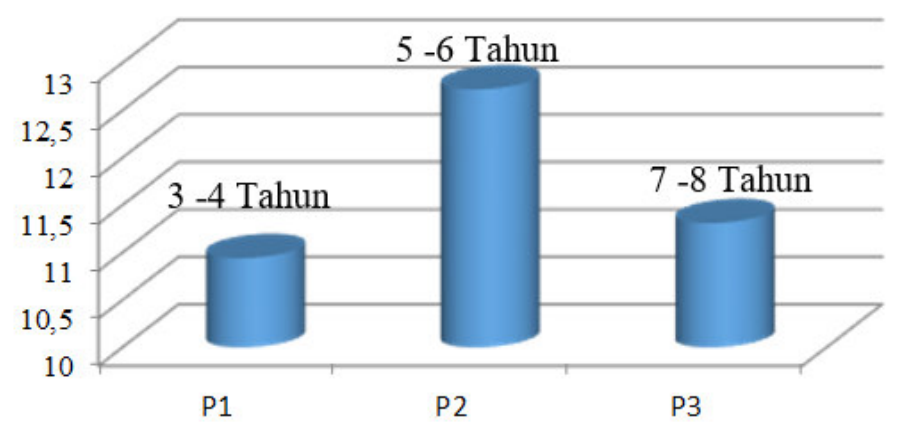

Gambar 1. Grafik umur induk dan umur lepas sapih 
Umur induk 5-6 tahun memberikan pengaruh terbaik terhadap produksi susu daripada umur induk 3-4 dan 7-8 tahun. Induk sapi pada kelompok umur 5-6 tahun memberikan produksi susu rata-rata yang terbaik yaitu sebesar 12,72 liter/ekor per hari. Produksi susu terendah terdapat pada umur induk 3-4 tahun yaitu sebesar 10,94 liter/ekor per hari. Tingginya produksi susu pada umur induk 5-6 tahun disebabkan oleh bertambah besarnya induk sapi karena pertumbuhan badan sudah maksimal dan jumlah sel dalam ambing juga bertambah pada saat laktasi ke 4 atau ke 5 dan mengalami penurunan produksi susu pada umur 7-8 tahun dikarenakan oleh aktivitas kelenjar - kelenjar ambing sudah berkurang. Rata-rata produksi susu sapi PFH di Pujon masih tinggi atau normal. Produksi susu ratarata sapi PFH di Indonesia 10 liter per ekor per hari atau kurang lebih $3.050 \mathrm{~kg} / \mathrm{laktasi}$. Produksi susu di Pujon masih tinggi disebabkan oleh oleh beberapa faktor antara lain pemberian pakan berupa konsentrat dan hijauan yang cukup dengan ketersediaan hijauan yang melimpah, kondisi iklim sesuai dengan habitat asli sapi PFH dan terlibatnya pegawai penyuluhan sehingga peternak mendapatkan pengarahan bagaimana cara yang baik memelihara sapi perah $\mathrm{PFH}$ (Amin, 2014; Sutiyono et al., 2017; Kurniadi et al., 2009; Sari et al., 2017).

Pada periode awal laktasi produksi susu tinggi tetapi pada masa-masa akhir laktasi produksi susu menurun. Kemampuan sapi perah berproduksi akan meningkat sampai tubuh mencapai umur 6-8 tahun setelah itu kemampuannya akan menurun. Hal ini disebabkan kondisi tubuh telah menurun dan senilitas (ketuaan). Meningkatnya hasil susu dari setiap laktasi dari umur 2-7 tahun itu disebabkan bertambahnya besar sapi karena pertumbuhan dan jumlah sel dalam ambing juga bertambah. Turunnya hasil susu pada hewan tua disebabkan aktivitas kelenjar kelenjar ambing sudah berkurang. Kemampuan seekor sapi dara untuk berproduksi tidak hanya dipengaruhi oleh pertumbuhan badannya, tetapi juga oleh pertumbuhan ambingnya yang mencapai pertumbuhan maksimum saat laktasi ke 4 atau ke 5 (Amin, 2014; Sutiyono et al., 2017; Kurniadi et al., 2009; Sari et al., 2017).

\section{KESIMPULAN}

Kesimpulan yang diperoleh dari penelitian ini adalah terdapat pengaruh umur induk terhadap produksi susu sapi perah PFH. Umur lepas sapih tidak memberikan pengaruh terhadap produksi susu sapi perah PFH dan tidak terdapat interaksi antara umur induk dan umur lepas sapih terhadap produksi susu.

\section{DAFTAR PUSTAKA}

Amin, R.U. (2014). Nutrition: Its role in reproductive functioning of cattle-a review. Veterinary Clinical Science, 2(1):1-9.

BPS. 2017. Kecamatan Pujon dalam Angka 2017. BPS Kabupaten Malang. Malang.

Hafez, B. and E.S.E. Hafez. 2008. Reproduction in Farm Animals. $7^{\text {th }}$ ed. Blackwell Publishing.

Kurniadi, R., M. Hartono, dan S. Suharyati. 2009. Faktor-faktor yang Memengaruhi Servis per Conception pada Sapi Perah Laktasi di Koperasi Peternakan Bandung Selatan Pengalengan Bandung Jawa Barat. Skripsi. Fakultas Pertanian. Universitas Lampung. Bandar Lampung.

Pineda, M.H. 2003. Veterinary Endocrinology and Reproduction. $5^{\text {th }}$ ed. Blackwell Publishing. Australia.

Riski, P., B.P. Purwanto, and A. Atabany. 2017. Produksi dan Kualitas Susu Sapi FH Laktasi yang Diberi Pakan Daun Pelepah Sawit. Jurnal Ilmu Produksi dan Teknologi Hasil Peternakan, 4(3):345-349.

Sari, E.C., M. Hartono, dan S. Suharyati. 2017. Faktor-Faktor yang Memengaruhi Service Per Conception Sapi Perah pada Peternakan Rakyat di 
Provinsi Lampung. Jurnal Ilmiah

Peternakan Terpadu 4(4).

Sutiyono, S., Samsudewa, D., dan Suryawijaya, A. (2017). Identifikasi Gangguan Reproduksi Sapi Betina di Peternakan Rakyat. Jurnal Veteriner, 18(4):580-588. 